\title{
Habeas Corpus, Its Versatility on Both Sides of the 'Pond,' and When Right against Remedy Becomes Quixotic
}

\author{
Thomas Curr \\ University of Cambridge, Cambridge, United Kingdom \\ thomas.curr@cantab.net
}

\begin{abstract}
This article examines the writ of habeas corpus ad subjiciendum and notes the greater use to which the writ has been put in the United States as compared to England and Wales, as well as an interesting conceptual problem identified in the US case of Hamdi $v$ Rumsfeld. The light shed by this discussion will assist examination of the reasons why habeas corpus ad subjiciendum has become more versatile in the United States than in England. It will be concluded that this difference reflects structural differences across the two jurisdictions, and that the writ in England and Wales - where it will be satisfactorily answered by a showing that someone is in custody pursuant to the order of a court with jurisdiction to confine him - does not need to be expanded beyond its current form, despite the greater American development of the habeas corpus concept.
\end{abstract}

\section{Keywords}

habeas - corpus - subjiciendum - Hamdi-Jane - remedial

This article ${ }^{1}$ examines the writ of habeas corpus ad subjiciendum and notes the greater use to which the writ has been put in the United States as compared to England and Wales, as well as an interesting conceptual problem identified in the US case of Hamdiv Rumsfeld. The light shed by this discussion will assist examination of the reasons why habeas corpus ad subjiciendum has become

1 I am grateful to Mr Alistair Mills and Professor David Feldman for comments on an earlier draft. 
more versatile in the United States than in England. It will be concluded that this difference reflects structural differences across the two jurisdictions, and that the writ in England and Wales - where it will be satisfactorily answered by a showing that someone is in custody pursuant to the order of a court with jurisdiction to confine him - does not need to be expanded beyond its current form, despite the greater American development of the habeas corpus concept.

The title here, referring to "Habeas Corpus," is really a shorthand. There actually are various writs of habeas corpus - as they are named in the Latin; the phrase "habeas corpus" gives the rough translation "you have the body." The writs of habeas corpus traditionally commanded the production of a person in court, for such purposes as the giving of evidence (habeas corpus ad testificandum) and the making of answer to an averment (habeas corpus ad respondendum) ${ }^{2}$

For these purposes, the habeas corpus writs commanded the production of the "body," as distinct very much from the corpse, of a prisoner, running to the person with custody of the "body." The writs commanded production of the body, which is to say the living person, in court, in order to fulfil the stated purpose - testifying, responding, etc.

The modern English and Welsh Civil Procedure Rules rename the writs ad testificandum and ad respondendum respectively as "habeas corpus to give evidence" and "habeas corpus to answer a charge." 3 This is unhelpful. The person on the street would recognise "habeas corpus" as a technical term. An attempt to make all legal concepts sound like "common sense" is quixotic; ${ }^{4}$ and equally quixotic, as we will see, is any attempt rigorously to distinguish right from remedy in all circumstances - even though the writs of habeas corpus are on their face remedies and not substantive rights.

Our focus here is on the "Great Writ" - that of habeas corpus ad subjiciendum. In its original form, the Great Writ commanded the production before a judge of a person currently detained, in order that the legality of that person's detention might be ruled upon, and if it were found unlawful the person's release ordered. The writ ad subjiciendum would go; the person would be brought into court; and the legality of the person's detention would then be decided by the court, one way or another.

2 Additionally, for the purpose of pursuing specified private pleadings (habeas corpus ad prosequendum). The full technical name for the "Great Writ" is the writ of habeas corpus ad subjiciendum et recipiendum.

3 Civil Procedure Rules 1998, rule 87.1.

4 That is, "foolishly impractical especially in the pursuit of ideals:" quoting the principal definition from http://www.m-w.com. 
In the modern day United States, the grant by a court of habeas corpus ad subjiciendum, which now will be abbreviated to habeas corpus, appears to represent a determination already made that a person's detention is unlawful. To grant the Great Writ, in 21st-century America, presupposes the invalidity of a person's detention; and it represents an order for the prisoner's release - whether conditionally, say if a state refuses to grant a state prisoner a retrial, or else unconditionally, say if the federal Bureau of Prisons has miscalculated a sentence, and so is actually holding someone without legal authority to detain them.

The privileged position of habeas corpus in both the US and the English and Welsh legal systems, reflects those systems' shared origins in the "Anglo-Saxon system of separated powers," the core "liberty" secured by which, was a "freedom from indefinite imprisonment at the will of the Executive. ${ }^{5}$ Compared to England and Wales, the device of habeas corpus has developed more in the American state legal systems and in the American federal legal system. A petition for the writ in those American systems may be used to attack a term of imprisonment which a prisoner has not yet begun to serve, or even to impugn a death sentence; in England and Wales, it seems that petitions for the writ are confined to claims that the actual physical custody is there and then unlawful. ${ }^{6}$ In the US, a habeas corpus petition is a versatile device for mounting "collateral" attacks on custodial and on capital sentences; in England and Wales, a showing that a prisoner's current physical custody is justified pursuant to the order of a court with jurisdiction to sentence him, will seemingly suffice to defeat a habeas corpus application. ${ }^{7}$

5 Hamdiv Rumsfeld, 542 US 507 (2004), at 554 (dissenting opinion of Justice Scalia).

6 In Jane v Westminster Magistrates Court [2019] EWHC 394 (Admin), a Divisional Court passed over (at [46]) the question whether the English writ of habeas corpus could, in principle, avail a person on bail rather than in actual custody. The "detention" had been authorised in any event by an order of a court with jurisdiction (see para [47]), enabling the "gaoler" (bailer?) to answer the writ. An assertion that the order, though extant, had been legally "flawed on various public law grounds" was an inappropriate ground for English habeas corpus (at [48]). For this purpose, legal error appears to be distinguished from jurisdictional error; the distinction is awkward because the current prevailing view in public law is that basically any legal error makes a decision ultra vires. To adopt Professor Christopher Forsyth's theory distinguishing between the "legal" and "formal" existence of a decision, Jane might be explained as holding that habeas corpus can attack only a decision's "formal" existence.

These restrictions on the English writ, reaffirmed in Jane, do not operate in the US. It should be said that Jane makes clear, nonetheless, that neither the statutory English appeal procedure under the Extradition Act 2003, nor the concept of judicial review (in which the grant of any remedy is discretionary) exclude operation of habeas corpus, in situations to which the Great Writ is genuinely applicable.

7 Here "defeat" is used in the sense that, though the writ may issue to bring the prisoner into court, it will not produce an order for the prisoner's release; interestingly, the modern 
But between England and Wales, on the one hand, and the United States, on the other hand, the habeas corpus concept is the same in its fundamentals. Whether in England or the USA, substantive law will determine whether a prisoner has a right to be released. If the prisoner has a right to release under substantive law, because the custodian lacks the right to hold him, habeas corpus is then a procedural mechanism by which the prisoner may vindicate his substantive right.

Habeas corpus has been put to a wide variety of purposes over the years, including to release a person detained invalidly under the colour of mental health legislation ${ }^{8}$ - and, more historically in the United States, to free persons incorrectly detained as slaves. ${ }^{9}$ The core function of habeas corpus has thus been to provide a remedy for unlawful detention of whatever sort. It is accompanied by the procedural right for the prisoner to be brought into court so that the legality of their detention can be determined, and if legal basis is found to be lacking then the prisoner's release ordered.

The Great Writ was in medieval England used to potent effect in the struggle between the Court of King's Bench, on the one hand, and the Chancery, on the other hand. Though a potent control on executive detention, the writ was also used to free persons committed to prison by the Chancery court for contempt of equitable orders prohibiting the enforcement of judgments obtained at common law from the King's Bench. This use of habeas corpus to nullify Chancery committals was apparently notable during the tenure of King's Bench Chief Justice Sir Edward Coke. After the Earl of Oxford's case ${ }^{10}$ in 1615 , the

English CPR give a judge the power to order immediate release in lieu of granting the writ. See Civil Procedure Rules 1998, rule 87.5, para (g). This highlights the lesser development of the English concept in comparison to the modern American one. As noted already, the American form of the writ now seems to be that of an order for (conditional or unconditional) release - in development away from the traditional form of habeas corpus ad subjiciendum still used in England, where the point of the writ is to bring the prisoner to court so that the court can decide whether detention is legal.

8 E.g. TTM v London Borough of Hackney \& ors [2010] EWHC 1349 (Admin).

$9 \quad$ Neely The Fate of Liberty (OUP 1991), p xiv: "By the 1850s, Republicans thought of the [habeas corpus] writ, if they considered it at all, primarily as a device to free fugitive slaves." The same page of Neely's book explains that the Suspension Clause of the US Constitution originally prohibited suspension outright; the qualification for cases of rebellion or of invasion was added later by "a vote of seven states to three," ibid. An additional use of the writ was that "[a]n apprentice, for example, could employ it to seek freedom from a master:" ibid.

$10 \quad(1615) 21 \mathrm{ER} 485$. 
primacy of equity over common law was established by decree of King James I presumably putting an end to this use of the Great Writ since, if equity were supreme, then detention on committal for disobedience to an equitable order could no longer have been held unlawful."1

While it can be seen that the English and Welsh system, on the one hand, and the US legal system, on the other hand, start from common roots and can be compared fruitfully as a descriptive exercise, the notion must be refuted that the world is a single legal community - such that judges in one country might cite as precedents decisions by courts in another country. At the risk of stating the obvious, different countries have different laws. From the point that an English case on an Act from 2006 would not be an authority on a domestic Act from 1996, it follows a fortiori that a US case about US law ought not to be an operative authority in an English case about English law. ${ }^{12}$ The late Lord Bingham, who believed in the use of foreign cases of authorities, ${ }^{13}$ fell into the trap of significantly misunderstanding what one of those authorities, namely Zadrydas $v$ Davis, ${ }^{14}$ was about. A habeas corpus case, Zadrydas involved an issue of statutory construction, and hence the (at least constructive) will of the US Congress - not a freewheeling articulation of values by members of a single worldwide judicial community. While a foreign case may supply a rule of decision in a case involving private international law, or might supply information, is submitted that an English court should never treat a foreign case as though it were a precedent on domestic law in any way.

Our conclusions about what US law is, ought not to be given normative weight on a question of what English municipal law ought to be. We can however consider - in a way that might inform some similar issues in English law a conceptual problem identified in the US case, which we have already have met, of Hamdiv Rumsfeld. ${ }^{15}$

Hamdi was a case in the US Supreme Court involving an application, for federal habeas corpus, by (the father of) a prisoner captured (1) in a zone of active combat abroad and presumed (2) to be a US citizen, brought to (3) the mainland United States - and (4) held indefinitely, perhaps even for "the rest of his life,"16 in (5) military custody, on (6) suspicion of having fought for the

\footnotetext{
11 I am grateful to Dr Neil Jones for a discussion of this point.

12 This simple argument gestures toward more highfalutin considerations about legitimacy and democracy. But sometimes simple arguments are the best: $c f$ the title of Judge Posner's article, "No Thanks, We Already Have Our Own Laws" - cited at n 47 infra.

13 See Bingham, Lives of the Law: Selected Essays and Speeches 2000-2010 (OUP 2011), ch 13.

14533 US 678 (2001).

15 Op cit.

$16 \quad 542$ US at 520 (plurality opinion).
} 
enemy, to wit the Taliban, in that foreign zone of combat. Although the US Supreme Court itself has power to grant "original" writs of habeas corpus, that "original" power is rarely exercised, and Hamdi was heard on review from the US Court of Appeals for the Fourth Circuit - appeal having been made to that court from the original filing of the petition in the district court for the Eastern District of Virginia.

Hamdi presented the issue of whether the petitioner could lawfully be detained based on the process he had already received - and, if not, what further process was necessary. The government argued that, so long as it produced "some evidence" to a court on habeas corpus supporting its determination that an individual - even a presumed citizen - was an enemy combatant, detention of such an individual was lawful because the President had inherent authority under Article II of the Federal Constitution to detain enemy combatants; further, that the federal "Non-Detention Act" did not apply to such military detentions ordered by the President; furthermore, that even were any authorisation by the legislature required, Congress' post-9/11 Authorization for Use of Military Force Resolution provided sufficient statutory authority for Hamdi's detention.

Hamdi postulated that his detention was both forbidden by the Congressional "Non-Detention Act" and violative of the constitutional guarantee against deprivation of liberty without due process of law, and hence that his habeas corpus petition should be granted and his immediate release ordered. His case, when decided, split the Supreme Court four ways. Justices Souter and Ginsburg would have "vacated" the judgment under review, which had been issued by the appeals court for the Fifth Circuit and had ordered the Federal District Court to dismiss the habeas corpus petition. The distinction between vacating and reversing judgments is not found in England and Wales. The nearest analogue to "vacatur" is a situation in the Criminal Appeal Act 1968, where an appeal is neither dismissed nor allowed; ${ }^{17}$ also analogous to "vacatur" is where a criminal appeal is allowed, but the consequent order quashing the conviction does not require entry of a judgment of acquittal due to being accompanied by an order for a retrial. ${ }^{18}$ In American terminology, to order a

17 Criminal Appeal Act 1968, c 19, s 3: where the jury "could on the indictment have found" the appellant "guilty of some other offence" (subsection (1)), the Court of Appeal "may, instead of allowing or dismissing the appeal, substitute for the verdict found by the jury a verdict of guilty of the other offence" (subsection (2)).

18 Criminal Appeal Act 1968, c 19, s 2(3): "An order of the Court of Appeal quashing a conviction shall, except where under section 7 below the appellant is ordered to be retried, operate as a direction to the court of trial to enter, instead of the record of conviction, a judgment and verdict of acquittal." 
retrial is to "vacate" rather than to "reverse" a conviction, and this illustrates the difference between the two dispositions. Justice Souter and Justice Ginsburg, having "vacated" but not reversed the Fourth Circuit judgment adverse to Hamdi, would have sent the case back to the lower courts for proceedings consistent with the view that, as developed so far in the case, the government's arguments had failed to overcome the statutory prescription in 18 United States Code $\S 4001(a)$. That section was referred to in the opinions in Hamdi as the "Non-Detention Act"; and it provides that a citizen may not be detained by the federal government otherwise than pursuant to an Act of Congress. ${ }^{19}$ If things were left there, Hamdi's release would be ordered on statutory grounds without the need to determine constitutional issues.

As regards the Non-Detention Act, the government had hinted at but had not actually presented an argument that the Act was unconstitutional on the ground that it impinged on the President's constitutional war powers. Had Hamdi gone back to the lower courts under Souter and Ginsburg's position, then, unless further argument against the constitutionality of the NonDetention Act or on another justification for Hamdi's detention availed the government in the subsequent proceedings, the petition for habeas corpus would have to be granted, and Hamdi's release accordingly directed.

There were only two votes ex facie for Justice Souter's disposition. So in the result, Souter - joined by Ginsburg - lent his vote to the outcome ordered by a four-justice "plurality." ${ }^{20}$ Adding the votes of Souter and Ginsburg to those of

19 Justice Souter remarked that the "tone" of the Non-Detention Act is "severe:" 542 US at 542 , quoting 18 USC $§ 4001$ (a) ("No citizen shall be imprisoned or otherwise detained by the United States except pursuant to an Act of Congress").

This is an odd comment. Laws state prescriptions; the Non-Detention Act, or indeed any other statute, seems pretty dry by colloquial standards. Maybe Justice Souter just meant that the wording of the NDA is universal and that the government's argument that the Act did not cover military detentions failed accordingly. Souter derived, at any rate, the requirement of "a clear statement of authorization to detain," from the NDA, and found such a statement to be lacking in any extant legislation.

The plurality - and, counting Justice Thomas, a majority of the Court - disagreed with Justice Souter on this point. To need to count a dissenting opinion as part of the majority on a particular issue, of course demonstrates quite how bizarrely the Court was split in Hamdi's case.

20 Justice Souter cited Screws $v$ United States, 325 US 91 (1945) at 134, where Justice Rutledge in similar fashion expressed a different opinion to those Justices whose posited judgment his vote supported, but lent his vote nevertheless in order to "produce a judgment:" 542 US at 553 . See also footnote 21 infra. When no opinion commands the concurrence of a majority of the Court, the most numerously signed opinion within the majority for the disposition is referred to as the plurality opinion. 
four other Justices, the "plurality" opinion's disposal of the case attracted a majority of the Court, and thus became the judgment. ${ }^{21}$ The four-justice plurality opinion vacated the Fourth Circuit's judgment and remanded Hamdi for further proceedings, but on different terms from those suggested in the main part of Souter's opinion.

Written by Justice O'Connor, the "plurality" opinion, which became the dispositive opinion, found - contrary to Souter's view - that Hamdi's detention had been authorised by Congress through the Authorization for Use of Military Force. But in the plurality's view, the constitutional right to due process of law - territory which Souter would have preferred not to reach - afforded Hamdi the right to contest the factual basis for his detention before a neutral decisionmaker. Because no such opportunity to contest the facts had yet been afforded to Hamdi, the court below, on remand of the case, was itself to conduct a hearing meeting the requirements of constitutional due process.

Justice Scalia was not impressed with this plurality opinion "transmogrifying the Great Writ." He observed that, "the role of habeas corpus is to determine the legality of executive detention, not to supply the omitted process necessary to make it legal." Certainly, Hamdi appears to be the first time that habeas corpus has been used to do this; having been used throughout history to determine the legality of all kinds of detention, the plurality in Hamdi extended the writ to supplying the process needed to legitimise detention.

Justice Scalia was also unimpressed by the "procedural novelties" invented by the plurality for application in such an "enemy combatant" proceeding including playing around with the burden of proof, which would in a civilian trial be squarely on the government, ${ }^{22}$ and admitting hearsay evidence. Scalia would have held that a citizen accused of wrongdoing, by aiding the enemy in wartime, could be detained only through the ordinary criminal process, with all of its safeguards - proof beyond reasonable doubt, exclusion of hearsay evidence, etc. - unless Congress implemented the clause of the Federal Constitution, the so-called Suspension Clause, allowing the writ of habeas

21 In US terminology, the "judgment" is the order made in the case, i.e. the result. What the English would call the "judgment" the Americans call the "opinion." The advantage in the American terminology is that "dissenting judgment" sounds like a contradiction.

22 US law does not permit the concept of an affirmative defence which the defendant must prove; such a concept is unconstitutional: In re Winship, 397 US 358 (1970). Were English courts to give normative effect to this doctrine of US constitutional law, numerous English laws requiring a defendant either to prove an affirmative defence on a balance of probability (a "legal" burden), or to adduce enough evidence to raise an issue on the defence (an "evidential" burden), would have to be rewritten. This observation amplifies points made infra about the dangers in citing foreign decisions as normative "authorities." 
corpus $^{23}$ to be suspended "when in Cases of Rebellion or Invasion the public Safety may require it."

All parties to Hamdi agreed that the Suspension Clause had not been invoked. So Scalia would have reversed the appeals court's judgment denying habeas corpus relief and would have remanded the case with instructions to grant the writ. The government "may then hand [Hamdi] over to the criminal authorities, whose detention for the purpose of prosecution will be lawful, or else must release" Mr Hamdi. ${ }^{24}$

In refutation of the canard that Justices Scalia and Thomas always voted the same way, Justice Thomas filed his own dissent - called a dissent because it argued for the polar opposite outcome than Scalia had done, and so remained a contrary view from a majority of the Court (the outcome ordered by the plurality-come-majority, charted a middle way between Scalia's desired ${ }^{25}$ outcome and Thomas' desired outcome). Thomas would have "affirmed" the judgment of the appeals court, hence denying the petitioner any relief and leaving Hamdi to be imprisoned for however long the President deemed necessary.

Dissenting in the opposite way from Scalia's dissent, and arguing that the judgment from the Fifth Circuit ought to be "affirmed," Thomas' opinion could have been taken from Nineteen Eighty-Four - arguing, as the opinion did, that the indefinite military detention of a US citizen, within the territorial jurisdiction of federal courts, had to be justified, under the constitutional Due Process

23 The actual phrase is "the privilege of the Writ of Habeas Corpus." This author, for his part, cannot see that anything turns on the phrase "privilege of," but $c f$ n 36 infra. Of course, what the provision means is the privilege of the writ of habeas corpus ad subjiciendum; the other habeas corpus writs do not have constitutional dignity.

24 What actually happened is that shortly after the US Supreme Court pronounced in his case, Hamdi did a deal with the administration to be released back to Saudi Arabia, on condition that the US government would not ask the Saudi government to arrest him there. Nonetheless, at the point when the opinions in Hamdi were issued, it looked wholly possible that "the government [might not] consider this unconventional war won for two generations" (542 US, at 520, plurality opinion) - and that Hamdi's imprisonment might therefore be lifelong.

25 The word "desired" is used here in the sense of a judge voting for an outcome. This may not be the same thing as a judge's political views or subjective values. Justice Scalia, for one, certainly claimed that his judicial philosophy separated his judicial duty from his personal opinions. See generally Scalia, A Matter Of Interpretation (Princeton, 1998). By the way, see Hollingsworth $v$ Perry, 570 US 693 (2013) for a 5-4 decision, not only with Scalia and Thomas on opposite sides, but with President Obama's two appointees on opposite sides. Scalia and Thomas also voted oppositionally in Alleyne $v$ United States, 570 US 99 (2013). The view of the US Supreme Court as mere politicians in robes represents cynicism unjustified by evidence, however "legislative" the Court may have become. 
Clause, only by "a good-faith executive determination."26 (A plurality of the Court recently said that "[o]nly a jury, acting on proof beyond a reasonable doubt, may take a person's liberty" and that this "promise stands as one of the Constitution's most vital protections against arbitrary government"; if so, then Thomas' opinion in Hamdi is abhorrent.)

To give Justice Thomas due credit, he voluntarily admits in his opinion that a case that might have been thought to support his view, actually involved aliens not American citizens; and, also, that a letter, from Thomas Jefferson to James Madison, provided "some evidence" that Justice Scalia's position had discerned the Constitution's original meaning. The intellectual honesty demonstrated in other contexts, where Thomas has confessed a realisation of past error, ${ }^{27}$ is displayed in Thomas' dissent in Hamdi and is to be commended.

That, unfortunately, is the only thing possibly to commend about Thomas's opinion. ${ }^{28}$ Aside from actually deploying the phrase "war on terrorism" in what should have been the serious context of a judge's opinion, ${ }^{29}$ Thomas' dissent canvasses case law substantially younger than the ratification date of the Due Process Clause - and relating to different issues ${ }^{30}$ - in order to assert that the

26 This went even further than the government's own position! See Part IV of Scalia's opinion, at 542 US 564 (the government argued that it should defeat a habeas corpus proceeding - or, in the traditional form, satisfactorily answer the writ when issued - if it could produce "some evidence" in support of "enemy combatant" designation).

27 E.g. Apprendiv New Jersey, 530 US 466 (2000) per Thomas J: he had in his own words "succumbed" to error in the earlier case of Almendarez-Torres, 523 US 224 (1998). He had by 2000 revised his position and argued for an even broader rule, quite contrary to his position in Almendarez, than that adopted by the majority in Apprendi - who carved out a narrow and arbitrary exception to the rule they announced in order to avoid overruling Almendarez.

28 This is not to suggest that Scalia's opinion is perfect either. Ex parte Milligan, a US Civil War case from the 1860s, might have force as precedent but it is impossible to see how Milligan could be evidence for the original meaning of the Constitution. Milligan was decided over 70 years after the Constitution was ratified and, in any event, by a wafer-thin majority of one vote. A one-vote majority is enough to set a precedent but is probably of nil evidential value in showing how a society understood a text.

29 O'Connor's plurality opinion quoted an almost identical phrase (542 US at 520 ) but put it in quotation marks. According to Part II of the plurality opinion, the government for its purposes in Hamdi claimed the authority to detain an individual whom it alleged had been "part of or supporting forces hostile to the United States or coalition partners" - and who had "engaged in an armed conflict against the United States." This is a much narrower concept than a generalised "war on terrorism."

30 How on earth is Moyers v Peabody, 212 US 78 (1909), a case "strikingly similar to this one"? Peabody was a suit for damages for false imprisonment ex post, against a state governor, and evidently turned on the concerns that would accompany the grant of a retrospective award of damages over executive action in emergency circumstances. What, therefore, does Peabody have to do with the original meaning of the Due Process Clause, as regards 
original meaning of a clause, proscribing deprivation of "liberty" unless accompanied by "due process of law," actually sanctioned indefinite executive detention. Thomas is, as Scalia was, an "originalist," seeking to effectuate the society's original understanding of the Constitution's text. So Thomas ought not to get away with appealing to a pragmatic analytical framework invented by a pragmatic judge, which is to say by Justice Jackson in Youngstown $v$ Sawyer, ${ }^{31}$ as the analytical anchor of his opinion.

As for the evidence, which, according to Justice Thomas' own judicial philosophy, ought to have been relevant to his view, Thomas' opinion misuses the Federalist Papers. He quotes Federalist No 23 as saying that authority "to protect the Nation 'ought to exist without limitation." What Federalist 23 did was to say that "The authorities essential to the common defense are these: to raise armies; to build and equip fleets; to prescribe rules for the government of both; to direct their operations; to provide for their support" - and then to say that "these powers ought to exist without limitation."

Worded in the way it actually is, Federalist No 23 offers no support for the view that the President's war powers are a steamroller over citizens' constitutional right to personal liberty, within the borders of the United States. ${ }^{32}$ The paper is talking about the power to raise and direct military forces, not about the relation of those military forces to personal liberty within the country. Thomas's citation of The Federalist drastically misuses it.

At any rate, the most interesting point in Thomas' opinion is that "I do not see how suspension" - that is, suspension of the writ of habeas corpus -

the process needed to defeat an ex ante application for habeas corpus by a person like Hamdi? Even as precedent, Peabody is a red herring. Scalia gives further reasons why Peabody is inapposite in his footnote 4: it concerned detention by a state militia during a state suspension of the writ; and it involved a "good faith" analysis that was a forebear of the modern qualified-immunity doctrine - which doctrine does not validate the underlying action in law but simply precludes damages. The same footnote to Scalia's opinion explains why Luther $v$ Borden, 7 How 1 (1849) - another case cited by Thomas - is similarly irrelevant: being a state case, Luther involved a situation where the state legislature had imposed martial law, an action "even more drastic than suspension of the writ" (542 US at 573).

31343 US $579(1952)$.

32 Yaser Hamdi had been captured in Afghanistan. But the location of capture cannot be determinative; it is the location of the detention that must matter. If the police arrest me to England, drive me to Scotland, and hand me over to the Scottish police, I might go to law in England to contest the legality of such a transfer but it nonetheless is the Scottish law on detention that becomes relevant to my continued situation. Justice O'Connor's opinion worried that, if she adopted Justice Scalia's rule, government officials would simply keep citizen-detainees abroad"; and asserted that Scalia had "largely ignore[d]" the context of the case, in which capture had occurred in a foreign combat zone. 
"would make constitutional otherwise unconstitutional detentions ordered by the President. It simply removes a remedy."

Justice Scalia's position, therefore, "might" - in Thomas's view - hence

"require one or both of the political branches to act unconstitutionally in order to protect the Nation. But the power to protect the Nation must be the power to do so lawfully."

The other reason for Justice Thomas's objection to Scalia's position, that there might be "many other emergencies" in which executive detention "might be necessary," was answered by Justice Scalia with the remark that it was "difficult to imagine situations in which security is so seriously threatened as to justify indefinite imprisonment" and yet the conditions of rebellion or invasion were not met. ${ }^{33}$

But Justice Scalia did not answer - and one might suspect Scalia could not answer - Thomas's more interesting point. "I do not see how suspension [of habeas corpus] would make constitutional otherwise unconstitutional detentions ordered by the President. It simply removes a remedy." Thomas' point can however be answered - and Scalia's view in Hamdi thereby vindicated. Sight of the answer will be had by casting a view back at the origins of the concept of a substantive right, vindicated by a procedural remedy.

While modern law postulates a substantive right and then asks what remedy might vindicate that right, ancient Roman law put things the other way around. A substantive legal right, if acknowledged at all, was something inferred from the availability of a remedy. For example, ownership - the right to control a piece of property - was something inferred by answering the question of who would win a "vindicatio" action to declare ownership. If the next praetor (lawmaker) added new remedies to the law, substantive rights would change by inference from the change in remedies.

The modern concept - that of granting a remedy by posing the question of which party had a substantive right - was in Roman law reversed. Modern Anglo-American law turns the logic of Roman law around. But that logic had

33 Anyway, since Scalia and Thomas both were originalists, their self-imposed task should have been to discern the Constitution's original meaning - as Scalia, one gets the impression, conscientiously tried to do - and not to weigh up pragmatic arguments. Nor did Thomas have the right, under his own judicial philosophy, to wade through a ream of later case law - and Thomas is normally, in the constitutional context, unmoved by precedent influenced heavily by pragmatic judges, and designed upon pragmatic arguments. 
not been turned around a full 180 degrees by the glory days of the Habeas Corpus Act.

The 1679 Act, as the distillation of the relevant history in Justice Scalia's Hamdi opinion shows, granted a prisoner certain remedies in certain situations. Right and remedy, in the 1679 Act, were rolled up inseparably together. To put it another way, the Habeas Corpus Act granted the right to a remedy in certain circumstances, making it quixotic to carve analysis of the right away from analysis of the remedy.

Blackstone, in his famous Commentaries of 1765 , is quoted in Scalia's opinion as saying that

"the parliament only, or legislative power, whenever it sees proper, can authorize the crown, by suspending the habeas corpus act for a short and limited time, to imprison suspected persons without giving any reason for so doing ... and in these [times] the nation parts with it[s] liberty for a while, in order to preserve it for ever."

So, in the medieval English law, what actually got suspended, in a time of public emergency, was the Habeas Corpus Act. "Suspension" actually suspended the whole statute, not just the writ of habeas corpus itself.

The Habeas Corpus Act rolled up right inseparably into remedy, as can be seen from the following extract from Scalia's opinion in Hamdi:

"As noted above ... § 7 of the [Habeas Corpus] Act specifically addressed those committed for high treason, and provided a remedy if they were not indicted and tried by the second succeeding court term. That remedy was not a bobtailed judicial inquiry into whether there were reasonable grounds to believe the prisoner had taken up arms against the King. Rather, if the prisoner was not indicted and tried within the prescribed time, 'he shall be discharged from his Imprisonment."'34

The prisoner, in the circumstances related, had a right to be released because the Habeas Corpus Act made a remedy available. Right was something created by remedy - just like in Roman law. When the medieval English Parliament suspended the Habeas Corpus Act, the medieval legislature suspended the combined package of right and of remedy.

It followed that the device of "suspension," when used, allowed the Executive 
"to imprison suspected persons without giving any reason for so doing" (Blackstone, as quoted by Scalia ${ }^{35}$ ).

But, to repeat, the "suspension" effectuated was of the whole Habeas Corpus Act. And so one now can see the root of Justice Thomas' problem. The US Constitution provides for the writ of habeas corpus to be suspended ${ }^{36}$ when certain exigencies, in Congress' judgment, ${ }^{37}$ so demand. In so providing, the Federal Constitution takes a tradition - that of suspending the Habeas Corpus Act in extreme situations - that dealt with right and remedy as a combined package, and seems to apply the concept underlying the tradition to a remedy that has been newly distinguished from the underlying right.

$35 \quad 542$ US at 561.

36 As previously observed, if there is any distinction between the writ and the privilege of the writ, then it is a distinction lost on this author, notwithstanding hints of such a distinction having been seen by some people. But $\mathrm{c} f$ Davis, A Treatise on the Military Law of the United States (LawBook Exchange, 2007), at 322. Davis seems to think that the privilege of the writ is the power of the court actually to order release when the custodian brings the prisoner to court, if the court - on return to the writ - should determine that the prisoner's detention really is unlawful.

This is not a persuasive distinction and, so far as original understanding goes, does not fit with the understanding manifested in the letter from Jefferson to Madison quoted by Scalia at 542 US 565 . The point of suspension is to remove, not only the power to order release of a prisoner but the power to disrupt emergency measures by having individual prisoners summoned into court.

If the distinction between granting the writ to bring the prisoner to court and actually ordering release of the prisoner was the distinction between the writ and the privilege thereof, then modern US law makes such a distinction in any event otiose. When a federal district court grants the writ, it has - in modern practice - already determined detention to be illegal and so is ordering (conditionally or otherwise) the prisoner's release.

37 Though the location of the power in Congress is not expressly stated, the placement of the Suspension Clause in Article I of the Constitution, which article enumerates the powers of Congress, seems to have given rise to virtually universal agreement that the "suspension" power granted by the Clause appertains to Congress.

An "originalist" should definitely agree with this conclusion. All "legislative powers herein granted" vest in Congress (Art I, s 1); and, given the tradition of "suspensions" passed by the English Parliament, the society of 1789 would have understood "suspension" to be a legislative power.

Blackstone, as quoted in Scalia's opinion, attaches particular significance to this point - calling it "the happiness of our constitution" that "the Parliament only, or legislative power" can determine the need for suspension. Blackstone, who wrote a famous commentary on medieval English law, is to an "originalist" relevant because the original understanding of the US Constitution would have derived from the medieval English understanding of concepts such as habeas corpus - hence Scalia's references. 
Justice Thomas' problem, in this way, can be resolved. Justice Thomas is engaged in an enterprise of trying to split up right from remedy in his analysis, concerning a clause built on a legal tradition that did not originally deal with a right distinguished from a remedy. If right and remedy are reunited - as Justice Scalia's position implies they must be - then Thomas' problem disappears.

An "originalist" approach, applied conscientiously, would end up at Justice Scalia's position. Originalism, as precisely defined by its chief proponents like the late Justice Scalia and Robert Bork, ${ }^{38}$ takes the society's original understanding of the constitutional text (not the subjective "intention" of the drafters or ratifiers) as the criterion of the Federal ${ }^{39}$ Constitution's meaning.

In 1789, when the Suspension Clause was ratified, the society - or at least, its educated members - would have been influenced by old English legal traditions. By the "suspension of habeas corpus," the society would have understood to be signified the suspension of the entire package of right and remedy against executive detention.

Put this together with the letter quoted by Scalia (a letter acknowledged even by Thomas to be "some evidence" for Scalia's position) - and Scalia's view is convincing. If Congress passes a law implementing the Suspension Clause, the package of right and of remedy, understood by the society of 1789 to be captured in the phrase "habeas corpus," is suspended to the extent stipulated by the law so passed. The law providing for suspension must, as distinct from what Scalia calls "ordinary legislation," of course meet the constitutional requirements of "Rebellion or Invasion" - though Scalia and Thomas actually agreed on the point that the Supreme Court could not review a determination by Congress, that the criteria of rebellion or of invasion, had been met. ${ }^{40}$

38 Bork, being a distinguished federal appeals court judge, was in 1988 nominated by President Reagan to fill the seat eventually filled by Justice Kennedy. A vigorous campaign was waged against Bork by Senate Democrats, and the nomination was defeated. The Senate had markedly woken up since confirming Justice Scalia by a 98-o vote in 1986.

An "originalist" state judge presumably looks, equivalently, at the original understanding that the society in a state entertained, of a state constitution's meaning.

40 As a reference for this, Scalia cited a passage from the commentator Joseph Story. See 542 US at 578 . As Story's commentary was published in 1833 , even that commentary might reasonably, as a source, be thought too young to prove original meaning from 1789. Furthermore, if one zeroes in on the "textualist" rather than the "originalist" aspect of Scalia's philosophy, and hence picks over the Suspension Clause word-for-word, then Lord Acton's famous "Alice in Wonderland" rhetoric from Liversidge $v$ Anderson [1941] UKHL 1 would perhaps justifiably mock the view that the words "public Safety may require" suspension can mean "if Congress thinks the public safety requires."

A pragmatic theory of law makes this part of Scalia's position (reconstituted as a formalist pocket, within a pragmatic jurisprudence) much easier to justify than under legal formalism (instantiated in originalism/textualism). The expertise to determine the necessity of suspension is located in Congress. And so a pragmatically sensible division of 
Because "habeas corpus," as the society of 1791 would have understood that phrase in the Suspension Clause, consisted historically of the package of right and remedy found in the Habeas Corpus Act, suspension of the privilege of the writ of habeas corpus should, in respect of the Suspension Clause, not be read so as to divide nuts unrealistically from bolts. Instead the phrase should be construed as a discrete term of art. "Suspension" should be held to permit, as a matter affecting both available remedy and substantive right, executive detention to the extent worked or authorised ${ }^{41}$ by an implementing Act of Congress. Right and remedy should be suspended by Congress in a package - such that executive detentions which normally would be both unconstitutional and remediable in habeas corpus, may for the duration of "suspension" become both constitutional and irremediable in habeas corpus.

This solution would seem to be a conscientious application of an originalist philosophy. No party to Hamdi contended that the Suspension Clause had been invoked. So Scalia's desired disposition of the case - remanding it with instructions to grant a habeas corpus decree, after which Hamdi would be prosecuted as an alleged traitor in the criminal justice system, or else would be released - is true to Scalia's convictions as an originalist. Justice Thomas's opinion, on the other hand, cannot be seen even as a tenable application of originalism; and - given that on a particular point, in footnote 6 , the opinion just cites the government's brief without stating its own analysis - fails to meet the minimum standards reasonably demanded of the United States' most powerful Court.

Scalia's position, that a citizen accused of wrongdoing by aiding the enemy can only be detained either through prosecution in the normal process or else by an Act of Congress under the Suspension Clause, can be defended not only in originalism but also under the pragmatic theory of law articulated by Richard Posner in Law, Pragmatism and Democracy. ${ }^{42}$

Posner constructs his theory of pragmatic adjudication by reference to John Dewey's observation, that law requires a logic - Posner corrects this

labour would commit judgment on this question to Congress. Cf Posner, Law, Pragmatism and Democracy, op cit, at 71 ("For judges to conduct guerrilla warfare against legislatures ... is destabilizing.")

41 Virtually everyone seems to agree, because the Suspension Clause is in Article I, which deals with legislative power, that the Clause delegates the "suspension" power to Congress. However, in the Civil War, Congress sub-delegated the "suspension" authority to President Lincoln - without apparent challenge. President Lincoln, on the back of the Congressional authorisation, subsequently suspended habeas corpus by proclamation.

42 Harvard, 2005 (p'back ed). Posner was, until his recent retirement, a federal judge on the US Court of Appeals for the Seventh Circuit. 
to "method" - relative to consequences, rather than to antecedents. This is, as Posner expounds it, a distinguishable principle from (pure?) "consequentialism"; for even a pragmatic judge "is not required or even permitted to take account" of all possible consequences flowing out of a decision.

Those consequences for the judge's finances, for instance, are out of bounds. Moreover - and most relevant to our inquiry here - pragmatism is not tunnel vision looking only at an individual case. As Posner expounds it, pragmatism demands attention to "systemic and not just case-specific consequences." ${ }^{3}$ Relevant systemic, which is to say systematic, consequences include the correct division of labour between courts and the other governmental branches very notably the legislature.

The issues in Hamdi are rife with systematic considerations. A pragmatic judge may, according to Posner, promulgate a jurisprudence incorporating pockets of legal formalism. Indeed, were this not the case, pragmatism would reduce every legal case to a balancing test. Pragmatism, as Posner puts it, is not synonymous with ad hoc adjudication - nor could ad hoc adjudication possibly be countenanced in areas of law like contract and intellectual property where predictable rules are, on account of systematic practical needs, demanded. ${ }^{44}$

Hamdi involved, one ought to suggest, an issue where - even on a pragmatic approach - a formalist cave is required. The formalistic rule suggested in Justice Scalia's opinion in Hamdi can, on pragmatic grounds, be justified as a formalist pocket within an overall pragmatic jurisprudence.

Scalia's suggested rule finds - if one applies Posner's theory of law - a supporting "resource" in the Suspension Clause, leaving it to the legislature to declare any qualifications to a normal rule, that executive detention - as opposed to detention in the usual criminal process - is forbidden.

The limitation of such a declaration to "Rebellion" or "Invasion" is not, under Scalia's system, a judicially reviewable question. So the "Rebellion"|"Invasion" requirement probably operates as a loose practical restriction: Congress would have, before authorising any sort of executive detention, to point non-laughably at some sort of "Rebellion" or "Invasion" if the public at large were not to think of Congress as acting unconstitutionally. The effect is basically that executive detention can be authorised, only where visibly necessary to meet an

43 Posner, op cit, at 59 .

44 "Uncertainty and interminability are pragmatic concerns, not pragmatic values:" Law, Pragmatism, and Democracy, op cit, at 63. Although legal pragmatism does not, as Posner explains, predetermine the value of specific consequences (as positives or as negatives let alone their precise weight as such), this passage seems to suggest that some consequences will be thought so universally bad as to eliminate any subjectivity in weighing those consequences negatively in the pragmatic exercise. 
identifiable exigency, arising from human action without or within, and not from natural disaster. ${ }^{45}$

Scalia's position is attractive, either under originalism, for reasons relevant to originalism, or under legal pragmatism, for reasons relevant to pragmatism. But to return, at any rate, to an earlier theme, the immense complexities of US law in this area - where the whole system is underwritten by a Federal Constitution, the method of interpreting which nobody agrees about - ought to illustrate British courts' folly in incautiously citing US precedents, as though the world were a single legal firmament.

We have already met Zadvydas $v$ Davis. Lord Bingham of Cornhill, sitting in the UK House of Lords in $A,{ }^{46}$ cited as an "authority" Zadvydas - presumably on the supposition that "the world's judges constitute a single elite community of wisdom and conscience" 47 - without any comprehension of the fact that Zadrydas had been a statutory case, turning on the "canon of constitutional avoidance." The canon of constitutional avoidance seeks to identify, or at least to impute, the will of the US Congress. Congress would not - so a judge presumes - want the constitutionality of its legislation even to be questioned, if the statutory language could conceivably be read in a way that circumvents the need for such unpleasantness.

By citing a case like Zadrydas, an English judge like the late Lord Bingham turns the European Convention on Human Rights - the thing he supposedly was interpreting - into a vehicle for transposing the actual or the constructive will of the US Congress into English domestic law. He had no warrant for doing so and to do so abdicated the responsibility he had as a judge conscientiously to effect a domestic legal text.

45 The word "emergency" is not actually used; had the Clause used the word "emergency," it would have stated a narrower requirement than "Rebellion" or "Invasion." Scalia's opinion in Hamdi seems to suggest that the quarantining of the infectious falls into a traditional, as opposed to a traditionally extraordinary, exception to the normal process of detention as an incident to or a consequence of prosecution for crime - and hence that a quarantine does not require suspension of habeas corpus to be validated under the Due Process Clause.

Scalia's point is that detention on the ground of an accusation of aiding the enemy in wartime is detention on the ground of an accusation of criminal activity, that is to say, of treason. And so detention on the ground of aiding the enemy has traditionally been permitted only through the normal criminal process, or else by suspension. The derogation clause of the ECHR is broader than the American Suspension Clause in that war or public emergency may trigger it, but narrower in that the emergency so specified must threaten the life of the nation and that the resulting derogation must be strictly required (rather than just required) by exigency.

$46 \quad A v$ Secretary of State for the Home Department [2005] U K HL 71.

47 Posner, No Thanks, We Already Have Our Own Laws (Legal Affairs, http://www.legalaffairs .org/issues/July-August-2004/feature_posner_julaugo4.msp, visited 3 March 2019). 
It all is a game, in any event. When Lord Bingham found a foreign case uncongenial he simply announced that, "this is not a precedent which I would wish to follow." 48 What on earth, then, has been achieved by consulting the foreign case, except to increase the materials needed to research a lawsuit, and therefore to put up the cost of litigation? If there were relevant information contained in the foreign case, then the case might have been worth looking at but this would require a determination of relevance of the information, not just a superficially ${ }^{49}$ similar legal issue arising in the case. The "precedential" citation of foreign cases amounts to wasteful "judicial fig-leafing."

And it is looking for fig leaves in bushes that English and Welsh judges are ill-equipped to delve into. Hamdi involved a complicated set of issues, beginning with Congressional law (had the generalised Authorization For Use Of Military Force, passed by Congress in the wake of the 9/11 attacks, authorised Yaser Hamdi's detention for purposes of the Non-Detention Act?) - and then moving to potential assertions of both parties, that the Congressional law, if it went against their position, should be held unconstitutional.

The plurality opinion, which became the dispositive opinion in Hamdi, found that the AUM F had authorised the President to detain Hamdi, assuming (as it said so meticulously) without actually deciding, that such authorisation was needed - that is to say that the President's "inherent" authority under Article II of the Federal Constitution did not supply sufficient authority for the detention and that the statutory Non-Detention Act correspondingly was constitutional. The government had hinted at an argument that the NonDetention Act was unconstitutional due to Article II; Hamdi's argument, on the other hand, was in effect that if the AUMF did authorise his detention, it was unconstitutional under the Due Process Clause.

On one way of looking at the outcome in Hamdi, the plurality opinion invalidated the AUMF as it applied to Hamdi's situation, in that the opinion required the authorisation in the AUMF for Hamdi's detention (which the

$48 \quad$ A, op cit, per Lord Bingham of Cornhill at [6o].

49 It is of course impossible for the same legal issue to arise in a foreign case; and if the difference between construing, say, the US Constitution and construing the European Convention on Human Rights has become a minor or even an irrelevant detail, then such a paradigm demonstrates that courts have drifted too far away from conscientiously applying the words of the democratically adopted texts in the name of which they make pronouncements. Even within Posnerian pragmatism, a systematic consideration is "the importance of preserving language as an effective medium of communication:" Law, Pragmatism and Democracy, op cit, at 62.

Note that whether or not a right to trial by jury is guaranteed depends drastically on the difference between the words of the ECHR and the words of the US Constitution. There are numerous other differences between the words of the two instruments. 
plurality found extant) to bow to the constitutional demands of the Due Process Clause. However the plurality defined those demands much less aggressively than Justice Scalia would have done; and, like Justice Souter but unlike the plurality, Scalia would not even have found the AUMF to authorise detention.

All of these complexities in Hamdi - statutory issues interacting with constitutional issues - are foreign conceptually as well as geographically to English and Welsh judges. English judges operate in a context of essentially unqualified parliamentary sovereignty, ${ }^{51}$ and the limitations on their perspective are starkly illustrated by Lord Bingham's mistake about Zadrydas. To cite Ham$d i$ as an "authority" in a case relating to, say, anti-terrorism orders in the UK, would be like using a dental implant to replace a toe.

In both World Wars, the UK Parliament passed legislation temporarily allowing detention of citizens by the Executive, on the ground of a mere suspicion that those citizens were aiding the enemy. The constitutionality of that legislation could not be questioned because the UK has no written constitution. ${ }^{2}$ The validity being that constitutionality of legislation is not at issue in the UK, as it is in the US. To repeat, the Hamdi plurality opinion arguably invalidated the AUMF, as the plurality construed the AUMF, "as applied" to Yaser Hamdi's case. ${ }^{53}$

In the United States, the existence of the Federal Constitution requires an analysis of a "Suspension Clause" based on a tradition whereby right and

51 The recent Miller case validates this observation. See [2017] UKSC 5.

$5^{2}$ Justice Scalia did not think Congress could be judicially reviewed over passing a law implementing the Suspension Clause; but he did indicate that he would vote to grant relief in the face of a law purporting to allow executive detention other than through the Suspension Clause - in other words, that he would vote to invalidate such a law, purporting to do what the Suspension Clause would authorise without stating a finding that the requirements of the Clause were met, as unconstitutional.

See 542 US at 575: "The Suspension Clause of the Constitution, which carefully circumscribes the conditions under which the writ can be withheld, would be a sham if it could be evaded by congressional prescription of requirements other than the common-law requirement of committal for criminal prosecution that render the writ, though available, unavailing" (emphasis in original).

53 The popular phrase where American courts "strike down" federal or state laws is infelicitous; most challenges to the constitutionality of laws are to those laws' application in particular circumstances. A court, in order to decide the case before it, does not "strike down" the statute but rather applies a constitutional provision over and above the statute in order to decree the resolution of the case.

"Facial," i.e. plenary, invalidation is the exception rather than the norm. It can happen where a statute can be demonstrated invalid in all possible applications; and also in the freedom-of-speech context, where the possibility of prosecution for valid speech under a law that also captures unprotected speech is held to be so unacceptable that the law per se must be invalidated. 
remedy were intertwined. The English and Welsh system means that the English writ of habeas corpus is best thought of simply as a remedy, albeit one to which some procedural rights attach. And of course, habeas corpus is a remedy rather than a right in the USA, too; but the American Suspension Clause, as we have seen, demands more flexible thought than a crude right-or-remedy analysis. The fact that, in England and Wales, a showing a person's physical custody implements an order by a court of non-defective jurisdiction (in a very basic sense of "jurisdiction," one distinct from the sense in which any public-law error goes to vires), will, as it appears, suffice to defeat an application for the Great Writ, makes English habeas corpus a much narrower remedy, as remedies go, than its American counterpart. This point refutes the illusion that the world is a single legal firmament. The English and Welsh judge consulting foreign cases as "authorities," probably does not know what he or she is doing. ${ }^{54}$

54 As an additional example of this, see Sharma $v$ Deputy Director of Public Prosecutions \& Ors [2006] UKPC 57. There Lord Bingham quotes (at [14]) Justice Powell from the US case of Wayte $v$ United States, 470 US 598, 607 (1985), describing "a decision to prosecute as 'particularly ill-suited to judicial review."'

In England and (as it appears) some Commonwealth countries whose judicial systems split from the English legal system significantly later than the United States did, "judicial review" is a type of claim, defined by rule 54.1 of the English Civil Procedure Rules as "a claim to review the lawfulness of - (i) an enactment; or (ii) a decision, action or failure to act in relation to the exercise of a public function" (subsection $(2)(a)$ ). That a defendant is a public body is not part of the definition, for a claim for JR is defined as including a request for "an injunction under section 30 of the Supreme Court Act 1981 [now Senior Courts Act 1981] (restraining a person from acting in any office in which he is not entitled to act)." The judicial review procedure in CPR Part 54 is a special procedure that must be used in a claim for judicial review seeking a mandatory order, a prohibiting order, a quashing order, and/or a section 30 injunction (rule 54.2); and which may be used for other judicial review claims seeking a declaration or an injunction (rule 54.3(1)). Judicial review claims are heard in the Administrative Court, which deals also with applications for English habeas corpus.

In the United States, "judicial review" lacks this specific English meaning (or meanings); and is a phrase used to describe administrative appeals, e.g. from the Board of Immigration Appeals, which is not a court constituted under Article III of the Federal Constitution, as well as the process of a court's passing upon the constitutionality and hence validity of a statute. For Lord Bingham to wrench a quote out of context in Sharma, op cit, from a US case simply because the US case included the words "judicial review" is, therefore, reckless, since it derives from a dissimilar context. And, since the US Supreme Court is not part of the judicial system of Trinidad and Tobago - from which Sharma came - Lord Bingham's citation might as well have been to a Schlotzsky's Deli menu, in terms of its legal authority.

Even if it could be argued that the point of principle is the same in this instance - the language in the US case about the difficulty a court encounters in reviewing an exercise of prosecutorial discretion, could be said to describe a comparable situation to a "judicial 
An English judge who might cite, as "authority," a US precedent on habeas corpus may not realise the enormous differences that 200 years of legal development, since the American and English systems split, have brought about. Incidentally, what the Americans call "remanding" a case the English call "remitting" a case; what English call the "judgment" Americans call the "opinion"; what Americans call the "judgment" is the outcome, not the reasoning behind the outcome; what Americans call "dismissing" an appeal is to refuse to entertain the appeal at all, say for lack of appellate jurisdiction; ${ }^{55}$ what the English call "dismissing" an appeal is for Americans to "affirm" a judgment being appealed.

And so on. Habeas corpus is used in the United States to review death sentences, to review sentences pending when a current sentence runs out, to "collaterally" attack criminal convictions, to review ordersfor a person's extraditionin other words, for far broader purposes than the English writ. In remedy, as in right, the English and Welsh judge ought in judging domestic law to mind his own precedents or, at most, to use foreign cases merely for information. Lord Bingham's mistake about Zadrydas ought to underscore this point.

In Zadrydas the US Supreme Court granted habeas corpus relief to an alien subject to a final order of removal (deportation). Ordinarily, as the Court explained, an alien ordered removed was detained during the 9o-day statutory removal period. The government had failed to remove Mr Zadvydas within the prescribed 90 days, and consequently 8 United States Code $\$ 1231(\mathrm{a})(6)$ authorised further detention beyond the removal period. Justice Breyer's majority opinion concluded that such further detention was authorised only so long as reasonably necessary to secure the alien's removal. ${ }^{56}$ Once that period

review" of such a discretion in the specific Commonwealth sense, that of an actual species of case - two problems remain extant.

First, an unfamiliar reader would think from Lord Bingham's quotation that "judicial review" existed in the US as a discrete species of case, which it does not. So the form of the quotation is potentially misleading. Second, the American position whereby prosecutorial discretion is an almost entirely executive prerogative (see Morrison $v$ Olson, 487 US 654 (1988), for a narrow exception that used to exist) and not suitable for questioning in a court of law, is not the English - or, presumably, the Commonwealth - position. Prosecutorial discretion, unlike in the US, sometimes is subjected to judicial review in England. Lord Bingham, therefore, quotes a principle arising from a dissimilar legal context in order to give that proposition normative weight, and to do so must be unwise.

The distinction between dismissing (in the narrow American sense) an appeal and "affirming" an appealed judgment was crucial in Pasha $v$ Gonzales, $7^{\text {th }}$ Cir, 29 December 2005. An English judge who dipped in to such an American opinion would be very unlikely to understand this distinction. 
was exceeded, the availability of some administrative review did not preclude an alien's right to release by means of habeas corpus. Jurisdiction was conferred on federal district courts by 28 USC $\S 2241(\mathrm{c})(3)$, which authorises issuance of the writ on the ground that a prisoner is "in custody in violation of the Constitution or laws or treaties of the United States" (with certain exceptions concerning state prisoners prescribed in $\S 2254^{57}$ ). While Supreme Court Justices, circuit judges of the federal courts of appeals, and federal district courts are all authorised to entertain applications for habeas corpus, ordinarily such proceedings are initiated in federal district courts. ${ }^{58}$

Although the Congressional Administrative Procedure Act set up a system of administrative review of deportation orders, such "statutory changes left habeas [corpus] untouched as the basic method for obtaining review of continued custody after a deportation order had become final. 59 Decisions specified, within the statutory removal scheme, as being within the discretion of the Attorney General were excluded from judicial review but pure discretion was not at issue here, where the "post-removal-period detention statute" 60 operated. Therefore, habeas corpus was available "for statutory and constitutional challenges to post-removal-period detention." ${ }^{61}$ Justice Scalia and Justice Kennedy's arguments in dissent were rejected. ${ }^{62}$ The fact that, unlike in England and Wales, ${ }^{63}$ habeas corpus is also the mechanism of reviewing extradition orders

57 See n 66, infra.

$5^{8} \S 2241$ of the US Code refers to "[w]rits of habeas corpus" rather than the writ ad subjiciendum specifically; and in authorising the writ where, concerning a prisoner, "[i]t is necessary to bring him into court to testify or for trial" (§ 2241(c)(5)), appears to cover the subject matter of the writ ad testificandum as well as that of the writ ad subjiciendum.

59 Zadrydas, 533 US at 687 (majority opinion) (emphasis in original).

6o Ibid at 688 .

$61 \quad$ Ibid.

62 Justice Scalia's dissent in Zadrydas, at 533 US 702-705, does not appear to question the scope of the writ of habeas corpus but rather to assert that there is no underlying right for the writ to vindicate. Zadvydas' claim was 'at bottom a claimed right of release into this country by an individual who concededly has no legal right to be here" (ibid at 703, emphasis in original). There was "no such constitutional right" (ibid). Unlike in Hamdi, the distinction between the remedy of habeas corpus and the underlying right vindicated by the writ was sustainable in the statutory territory trodden in Zadvydas; the suggestion here that right and remedy be analytically reunited is applicable only to the constitutional Suspension Clause (and to understanding its concept of suspension - which derives from English suspension of a statute rather than of a remedy per se). In Zadrydas, Justice Kennedy criticised, e.g. at 708, the Court's statutory interpretation, including the invention of a presumptive 6-month period after which the onus would shift to the government to show that removal of the alien was reasonably foreseeable and continued detention therefore authorised. Again, Justice Kennedy did not appear to question the applicability of the habeas corpus writ itself.

63 See the Extradition Act 2003, c 41. 
in the United States, sets into relief the broad variety of purposes to which the writ is put in the US - more so than in England and Wales.

Taking US experience as an illustration, rather than as instruction, should the comparatively narrow English concept of the Great Writ - or as it now is called with rather less dignity, "habeas corpus for release" ${ }^{\text {"64 }}$ - be expanded?

It probably ought not to be expanded in England and Wales. Because of the paradigm of overlapping state and federal laws, both of them being applied in state courts and in the federal courts, ${ }^{65}$ the US legal system is fundamentally just a lot more complex than the English and Welsh system. The presence of a written federal constitution, not to mention written state constitutions as well, adds another source of complexity; inquiry into the validity of a criminal trial is, even if the applicable procedural statute is complied with, only just beginning; the procedural statute might be unconstitutional! The need to use the federal writ of habeas corpus deferentially ${ }^{66}$ to review state court

64 CPR 1998, rule 87.2.

65 Rumsfeld $v$ Padilla, 542 US 426 (2004), decided the same day as Hamdi, and on procedural grounds - the lawyers for the alleged "enemy combatant" in Padilla should, under timehonoured habeas corpus principles, have sued the commander of the naval brig having custody of the prisoner, and should not have sued Defense Secretary Rumsfeld - saw consideration taken of New York's state law about "long-arm jurisdiction"; the state law had a bearing on the availability or otherwise of the federal writ. See 542 US, at 433,444 (opinion of the Court).

The same opinion, remanding Padilla's case to be dismissed without prejudice (that is, prejudice to his right to re-file in the correct court), remarks pertinently that "a simple challenge to physical custody imposed by the Executive" is "the traditional core of the Great Writ:" ibid at 441.

6628 United States Code $\S 2254$ (d): a claim for federal habeas corpus by a state prisoner shall be granted "with respect to any claim that was adjudicated on the merits in State court proceedings" only if "the adjudication of the claim was contrary to, or an unreasonable application of, clearly established federal law, as determined by the Supreme Court of the United States" - or else if the state court has unreasonably determined the facts in light of the evidence given at the state court level. (In the latter event the prisoner has the onus to refute the state determination by "clear and convincing evidence" - a sort of American middle ground between a "balance of probability" and "beyond reasonable doubt.") The "unreasonable application" test in $\S 2254$ is an interesting analogue to the Wednesbury test in English and Welsh public law.

Unlike Wednesbury, however, the test in $\S 2254$ governs questions, which, in their own right, are questions of law. Peter Cane writes, concerning points of English law, that it would be "realistic to allow that questions of law sometimes admit of more than one reasonable answer than to insist that a question of law can only ever have on right answer:" Cane Administrative Law (oup 2004), at 244. Cane's suggestion (at 245) that errors of law "within jurisdiction" ought to be reversed by the superior English courts only "if the answer given is unreasonable in a rather extreme sense," actually states fairly precisely the test for federal-court intervention, upon habeas corpus, against state courts under $\S 2254(d)(1)$ in the US. Federal courts must, in giving effect to $§ 2254(d)(1)$ in respect of a state decision that did not mis-identify the governing legal rule and was thus not 
determinations of federal (including federal constitutional) issues arising in state criminal trials, arises from the overlapping state/federal framework. This is one of many complexities present in America but absent in England and Wales.

The power of the Criminal Cases Review Commission, see Criminal Appeal Act 1995, to permit appeals to the Court of Appeal (Criminal Division) once a first appeal has failed, or once the time limit for filing a first appeal has expired, substitutes sufficiently for the broader US concept of "collateral" attack on a criminal conviction, through an application for habeas corpus. The Commission is created by Part II of the Criminal Appeal Act 1995. Its principal function $^{67}$ is to make references to the Court of Appeal, which then are treated "for all purposes" as appeals against the convictions and/or sentences referred. ${ }^{68}$

In the light of practical necessities, the US concept of habeas corpus ad subjiciendum has developed from its medieval roots far more than the English and Welsh concept. Those practical needs do not obtain on the eastern side of the Atlantic, and justify the English failure to expand the notion of habeas corpus beyond inquiry into the jurisdiction (or maybe "formal existence" 69 ) of the authority by which detention has been directed.

"contrary to" USSC precedent, whether the application of USSC precedent was "objectively unreasonable:" Williams v Taylor, 529 US 362 (2000) at 407-409 (O'Connor, J, delivering opinion of the Court in this part of her opinion). This is a stronger standard even than "clear error"; and the Ninth Circuit appeals court has been reversed for "conflating error (even clear error) with unreasonableness:" Lockyerv Andrade, 538 US 63, 75 (2003).

Interesting though this all is, all of these complications demonstrate what a barbed thicket of unfamiliar concepts English judges wade into, when they consult US cases as normative "authorities." The risk of misinterpretation is huge, aside from the question of how US law can have any democratic legitimacy in the UK.

67 The Commission may also conduct investigations at the direction of the Court of Appeal (section 15); and may assist the Secretary of State in advising the Queen when exercising her prerogative of mercy (section 16). The Commission's investigatory powers are found in sections 17 to 22 of the 1995 Act.

68 Criminal Appeal Act 1995, section 9. It is the Commission's power to refer convictions which is most clearly analogous to the aspects of American habeas corpus that go beyond the English use of the writ. However, the power to refer sentences - once the time limit for an initial appeal against sentence has expired - could be compared to an American petition for habeas corpus brought to attack a sentence as being unconstitutionally "cruel and unusual." This was done in Lockyerv Andrade, op cit at n 66 supra.

69 See n 6 supra. 